現代夫婦の勢力関係研究についての一考察

一バーゲニング・モデルの提示ー

片岡佳美

Key words : 等力、選好、バーゲニング・プロセス

\title{
1. 研究の動機と目的
}

現代日本の家族に、平等化、個人化、多様化などの新しい現象が生じてきていることは、これまてに 多くの文献において述べられてきている。にもかかわらず、家族社会学におけるアプローチやパースペ クティウには、それに対応した変化がほとんどみられない。いま、このような点についての再考・転換 が迫られている [野々山，1996]。家族の变勏に伴い、家族研究の枠組や方法も変わらなけれは、現在 の家族についてはもちろん、これからの家族について理解することはできない。

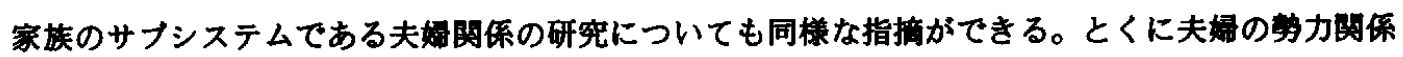
(power relationships) の研究は、フェミニズム草䡃の影雾を受けてアメリカでは、1950年代後半か ら70年代にかけて盛んに行なわれた。しかしフェミニズムの思想が一般化するにつれて、研究者の夙心 を引かなくなっていった。近年においては新しい研究成果はほとんどみられない。アメリカの研究成果 に侬存してきた日本の㐘力园係についての研究は受動的にそのような研究事情を反映し、20３0年前か ら進展せずに放畫されたままのアプローチによって今日なお現代夫嫌の势力闺係が説明されようとして いる。しかし家族が変動期にあるといわれる今日、势力研究についても以前とは逜ったアプローチを用 いなければ、現象を正礁に俣えることはできない。

本論では、夫嬬の喽力関係の研究の発展にむけて、新しいアプローチに基づく仮説的モデルの提案を

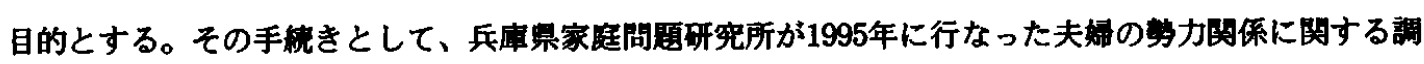

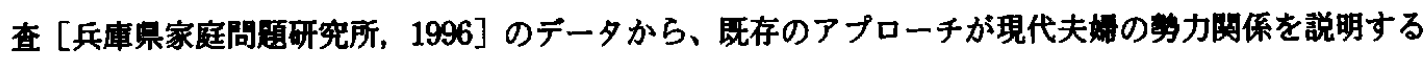
のに有効でなくなってきていることを実証する。

\section{2 . 既存の理論とアプローチ}

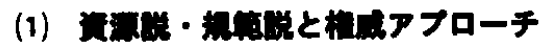

多力関係は、多力の大きさの比較を行なうことによって説明される。スキャンソーニは既存研究のレ ウューを通して、その方法について詥じている [Scanzoni，1979］。すなわち第力関係は、意四通りの 結果をより多くもたらすことができるのは誰かを、当事者間で比較・評価することによって説明される、

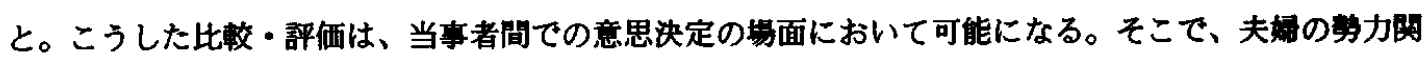
係についての説明はこれまで、夫娜間での意思決定に焦点を当てて試みられてきた。

なかでもブラッドとウルフによるアメリカ・デトロイトでの調查研究は、後の研究者に大きな影謷を 
与えた [Wolfe, 1959; Blood and Wolfe，1960]。彼らは、既婚女性に対し、家族生活における8つ の領域の問題について、どちらの配偶者がいつも最終決定をくだしているかを尋ねた。その反応から直 接夫婦の勢力関係を捉え、資源説を導きだした。すなわち職業的威信、収入、最終学歴などといった社 会経済的資源をより多くもつ配偶者は、夫婦間の意思決定において勢力がより大きいという関係を命題 化した。

一方、ビューリックとゼセウィックは、ブラッドらと同様な方法を用いた既存のギリシアやユーゴス ラヴィアについての調查に言及し、それらの社会では資源説が成り立たないことを見いだした [Buric and Zecevic, 1967]。彼らは、これらの社会では夫唱婦随であるべきという規範が根強く残っている ために、そうした結果になったと説明する。これは規範が勢力関係に影響するという規範説にほかなら ない。

以後、日本の研究者を含めた多くの研究者は、ブラッドらの方法を用いて夫婦の勢力関係を論じてき た。ところが、オルソンとラビュンスキーは、ブラッドらの方法からは、各配偶者の勢力の大きさでは なく、むしろ権威の大きさが引き出されるという [Olson and Rabunsky, 1972:229]。権威 (authority) とは、ブラッドらの定義によれば、勢力がより大きいことの正当性の認知に基づくもの である [Blood and Wolfe, 1960：11]。たとえば夫婦間の意思決定において、一方の配偶者がより 優位な立場にあることが正当だと認められていれば、その人により大きな権威が配分されているという ことになる。

オルソンらによると、ブラッドらが分析に用いた、回答者が普段の自分たち夫婦の関係を思い出して 行なった報告は、その回答者自身によって正当だと認知される夫婦関係を反映する。この点で、権威の 大きさが測定されるとはいえ、それは客観的な夫あるいは妻の権威の大きさというよりも、その回答者 が自分や配偶者に配分する権威の大きさを導きだすことになる。したがって、資源説や規範説は、個人 が自分自身や配偶者に配分する権威の大きさについての理論ということになる。

当時は、夫唱婦随であるべきという規範が多くの社会で根づいており、アメリカではようやくそれが 弱体化し始めてきているという状況であった。したがってアメリカでは、夫唱婦随の規範が弱まるなか、 そのような規範を強く内面化した夫は、自分の社会経済的資源の多さを背景に、何とか意思決定におい て自分が妻より大きな勢力をもっていることを正当化し、優位な立場を守らなければならなかった。一 方、ギリシアやユーゴスラヴィアでは、まだそうした規範が圧倒的に有力で、文化的性差という根拠の みで夫はより大きな勢力を正当化することができた。

いずれにせよ、夫唱婦随的な規範が人びとの意識や行動に、何らかの影響力をもっている時代では、 夫に配分される権威の大きさが問題となった。そしてそれだけ一層、夫の権威の大きさが彼の勢力の大 きさに直結しやすかったのであろう。したがって当時においては、こうした権威アプローチによる勢力 研究の意義があった。しかし、そのような規範が完全に影響力をもたなくなると、状況は異なってくる。

\section{(2) 統制アプローチ}

ロドマンやバーは、規範的資源説（文化的文脈における資源説ともよばれる）を示し、資源説と規範 説を統合した [Rodman, 1967 ; Burr, 1973]。この理論によると、勢力の大きさと、職業的威信、最 
終学歴、年収といった社会経済的資源との関係は、規範に影響される。夫婦平等の規範が浸透している 社会では、勢力と資源のあいだに正の相関関係が、夫唱婦随の規範が浸透している社会では、勢力と資 源のあいだに負の相関関係が成り立つ。つまり、勢力をめぐるバーゲニングは、規範によってそれぞれ 意味づけられた社会経済的資源の交換を意味する。

しかしこの理論は、それ以前の権威アプローチに基づく研究から導きだされたものであるため、ここ でいう勢力は、ある人が配分する権威の大きさと同義である。この点で、次のような問題が浮上する。 すなわち、夫婦が対等な立場から意思決定を行なうようになると、両配偶者に同じ大きさの権威が配分 されるようになる。したがって、だれの権威がより大きいかはもはや問題にならないはずである。そう すると、ある人が自分や配偶者に配分する権威の大きさから直接、夫婦の勢力関係を導きだすことはで きないのではないか。

コーレイルズは、権威以外に勢力を測定する基準として、意思決定での交渉における統制（control） を重視する [Corrales, 1975]。統制は、意思決定のさいの交渉を通して生じる。統制がより大きい配 偶者とは、交涉において相手を妥協させ、自分の意見に合意させることができた者である。

夫婦が対等な関係になってくると、夫婦間の意思決定は夫婦で話し合って、つまり交涉を経て行なわ れるようになる。このように、交渉における統制の大きさの比較をもって夫婦の勢力関係を明らかにし

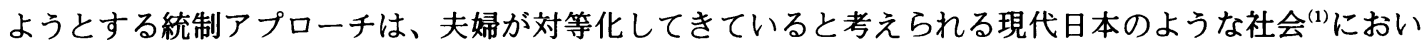
ては有効だろう。しかし日本の勢力研究では、増田光吉による1963年の神戸市における調查研究以来 [増田, 1965］、最近でもブラッドらにならった権威アプローチが採用されている [伊藤, 1986 ; 菰渕, 1992]。

とはいえ、アメリカの既存研究においても、統制という概念は、たとえば夫婦の結婚満足度やストレ スの克服の速さといった目的変数を説明するために用いられてきた [Kolb and Straus, 1974; Corrales 1975]。 そのため、残念ながら権威アプローチで試みられてきたような、勢力の大きさを目的変数とした理論の 発展には寄与してこなかった。したがって、統制の大きさから直接、勢力の大きさを論じることができ るか否かについては、いまなお明らかにされていない。

\section{3 . 統制アプローチの有効性の検証}

\section{(1) 調査の概要}

前章をふまえて本章では、勢力関係研究の発展に向けての 1 ステップとして、兵庫県家庭問題研究所 による1995年の調査データから、既存のアプローチの有効性を検証する。

この調査は、兵庫県在住の 20 歳以上の既婚女性を対象に行なった郵送による質問紙調查である。サン プルは、層化多段抽出法によって選定した 7 地区（ 2 区、 4 市、 1 町）の選挙人名簿から、各層の 20 歳 以上の女性人口の比率に従って2000名分無作為抽出した ${ }^{(2)}$ 。有効回収票数は674票で、回収率は $33.7 \%$ である。

データの特性としては、居住地の分布の点で、町から得たデータがやや多め（母集団比率 $9.0 \% に$ 対 し有効サンプル比率12.9\%）になったが、全体的には母集団と大きな差はない。妻の平均年齢は48.81 歳（ $\mathrm{sd}=11.58 ） 、 夫 の$ 平均年齢は51.75歳（ $\mathrm{sd}=12.03 ）$ であり、母集団比率と比べ、調查データは中 
高年層にやや偏っている。そのため回答者の末子は、48.5\%が社会人、10.4\%が短大生以上に属し、6 割近くの夫媂が脱子有て期にある。

\section{(2) 仮眖}

統制アプローチの有効性を娭証するために、まず「夫姆間の意思决定では、二人で話し合って決める という夫婦が多い」という仮説(1)を設定した。話し合って決める夫短がかなりの割合を占めれば、回答 者の多くは自分と眼偶者に対して同じ大きさの権威を盼分しているということになる。したがって、第 力関係を説明するのに権威アプローチは有効ではないとされ、統制アプローチの可能性が開ける。

しかし、仮説(1)が成り立ったとしても、交渉の結果だれの統制が大きかったかということから、勢力 の大きさを直接評価してもよいか否かという問題が残されている。

規籁的資源説に従って考えると、統制が勢力と同娄であるならば、势力をめぐるバーゲニングである 社会経済的資源の交換が、統制の大きさが問道になる交渉の場面においてなされているはずである。そ こで、「意思決定のさいの交涉における疌の統制の大きさと社会経清的資源の多さとのあいだに、相网 関係が成り立つ」という仮説(2を設定した。その相関閶係の正負は、その社会に浸适している規籍に侬 存する。この仮説(2)か㬰証されれば、「交涉における共の統制の大きさイコール妻の苏力の大きさ」で ある可能性がある。

\section{(3) 分行方法}

仮説(1)(2)検証には調查票の、今年の更期休㗇・最近の年中行事・テレビ番組の優先権・夫の友人の 訪問・最近の家族旅行・結婚後の妻の就兼の 6 項目の意思決定 ${ }^{(3)}$ についての䨘問に対する回答結果を用 いる。

まずそれそれの意思決定項目について、「夫が一人で決めた」「疌が一人で决めた」「夫婦で話し合っ て決めた」のうち、どれであったかを貫問した。これらの意思決定では「いつも」だれが決めているか と䑧ねてしまうと、ブラッドらが用いた测定方法と同じ（つまり権威アプローチ）になってしまうので、 いずれの項目も 1 回きりの意思決定について回答を求めている。仮説(1は、「夫婧で話し合って決めた」 がかなりの割合を占めていれば成立する。

次に、各意思決定項目で「夫婦で話し合って決めた」というケースについて、交渋の結果「妻がかな り妥協した」「どちらかというと妻のほうが妥協した」「両方が同じだけ妥協した」「どちらかという と夫のほうが妥協した」「夫がかなり妥協した」のどれであったかを尋ねた。自分が妥協せず夫が妥協 したという妻ほど、交渉における統制がより大きいということになる。この5つの反応カテコリーに対 して面に 1 点から 5 点を与え、全6 項目での平均点を割りだし、これを妻の統制の大きさのスコアとし た。6 項目全部に答えていないケースについては、回答した項目数で合計得点を割っている。したがっ て、スコアが 5 点に近いほど、交渉における妻の統制がより大きいことになる。

説明変数である社会経済的資源としては、規籍的資源説が資源として扱っている、夫と妻の僟業的威 信(4)・最終学歷・年収を取りあげている。 


\section{(4) 結 果}

仮説(1)を検証した結果、各意思決定で「夫婦で話し合って決めた」の割合は大きい。6 項目中 5 項目 において、話し合って決めたとする割合は、一方の配偶者が独断で決めたとする割合を超えている（図 -1)。このことから仮説(1)は成立する。そして勢力関係を明らかにするには、もはや権威アプローチ では不十分になってきていることが示された。

次に仮説(2)についてであるが、まず、各意思決定項目での妻の統制の大きさについての得点を調べた ところ、だいたい中間点よりやや上ぐらいに位置している（表-1）。各ケースの妻の統制の大きさの スコアの平均は、 2.84 点 $(\mathrm{sd}=.49)$ となった。

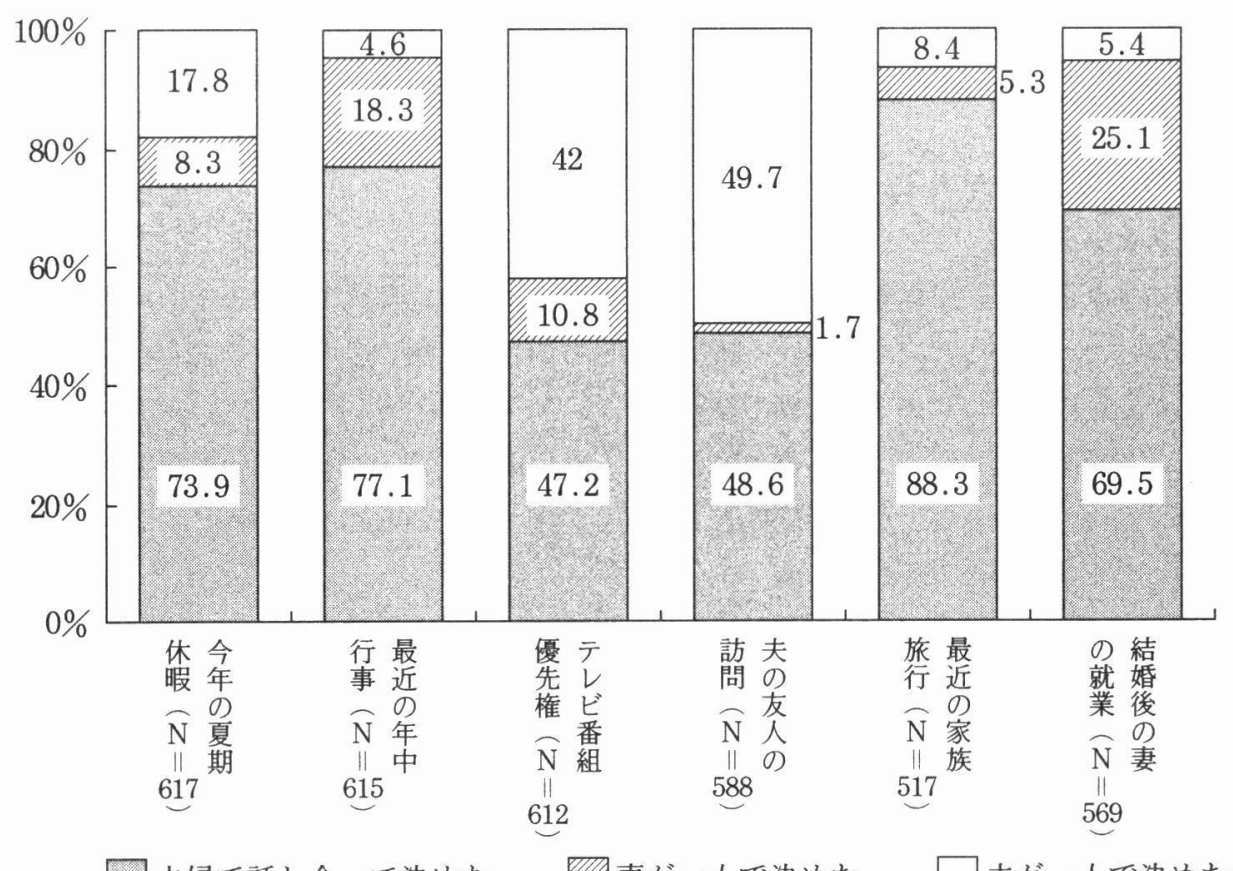

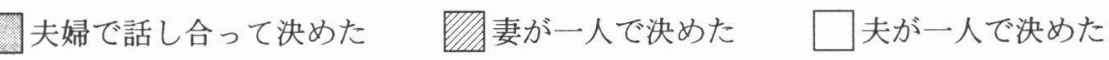

注 : 合計は、まるめのため100\%にならない場合がある。

図-1 意思決定各項目での決めかた

表- 1 妻の統制の大きさの得点の平均・標準偏差・有効ケース数

\begin{tabular}{|c|c|c|c|}
\hline & 均 点 & 標準 偏 差 & 有効ケース数 \\
\hline 今年の夏期休暇 & 2.91 & .68 & 375 \\
\hline 最近の年中行事 & 2.87 & .63 & 467 \\
\hline テレビ番組優先権 & 2.79 & .85 & 291 \\
\hline 夫の友人の訪問 & 2.57 & .69 & 286 \\
\hline 最近の家族旅行 & 2.97 & .57 & 487 \\
\hline 結婚後の妻の就業 & 2.95 & .77 & 384 \\
\hline
\end{tabular}


表ー 2 に示すように、妻の実際の統制の大きさは、いずれの社会経済的資源とのあいだにも統計上有 意な関係はみられない。つまり、交渉において、勢力をめぐるバーゲニングが行なわれていることの指 標となる資源の交換はなされていない。したがって仮説(2)は成立せず、交渉における統制の大きさから は直接勢力の大きさを論じられない。

表ー2 妻の統制の大きさスコアと社会経済的資源との相関関係（有効ヶース数）

\begin{tabular}{|c|c|c|c|c|c|c|}
\hline & $\begin{array}{l}\text { 妻 } \text { の } \\
\text { 職業的威信 }\end{array}$ & $\begin{array}{ll}\text { 妻 } & \text { の } \\
\text { 最終学歴 }\end{array}$ & 妻の年 収 & $\begin{array}{l}\text { 夫 } \quad \text { } \\
\text { 職業的威信 }\end{array}$ & $\begin{array}{ll}\text { 夫 } & の \\
\text { 最終学歴 }\end{array}$ & 夫の年 収 \\
\hline 妻の統制の大きさ & .0099 & -.0122 & .0070 & .0018 & -.0306 & .0069 \\
\hline スコア & $\begin{array}{c}\mathrm{P}=.815 \\
(565)\end{array}$ & $\begin{array}{c}\mathrm{P}=.766 \\
(596)\end{array}$ & $\begin{array}{c}\mathrm{P}=.867 \\
(571)\end{array}$ & $\begin{array}{c}P=967 \\
(534)\end{array}$ & $\begin{array}{c}\mathrm{P}=455 \\
(596)\end{array}$ & $\begin{array}{c}P=868 \\
(578)\end{array}$ \\
\hline
\end{tabular}

\section{4. 夫婦の勢力関係モデルについての考察}

\section{(1) プロセスという視点}

仮説検証の結果から、現代日本の夫婦の勢力関係を説明するには、権威アプローチでは限界のあるこ とが明らかになった。しかし、交渉における統制の大きさから直接勢力の大きさを捉えられないことが 示されたことから、統制アプローチも有効でない。

「交渉における統制の大きさイコール勢力の大きさ」という考えは、交渉において相手より自分の方 が統制の大きさが大きくなることが、各配偶者によって意困されていることを前提とする。だが、この 点に問題があるのではないだろうか。

話し合って意思決定を行なうという関係は、必ずしも交渉において勢力をめぐるバーゲニングを生ず るとは限らない。互いの意見を述べ合うことが前提とされているだけであって、ある領域での意思決定 では、相手の方が率先的になって自分より大きな統制を示すことを望ましいとし、それを実現させたが る配偶者もいるだろう。各配偶者は意思決定のたびに、それぞれが望ましいとする意思決定における夫 婦関係を実現させるために、あれこれと戦略を練っている。そして、自分の思い描く夫婦関係を、実際 の意思決定での夫婦関係においてより多く実現させようと、両配偶者のあいだでバーゲニングが起こる。

実際、調査での自由回答欗をみると、夫婦で話し合った結果、妻の意見が通ってもそのことを妻が不 服としていたケース、また夫の意見ばかりが通っていても妻がそれに満足していたケースなどがあった。 ある意思決定領域で話し合いを経た結果、自分の統制の大きさの方が大きかったとしても、その人がそ れを望まないのであれば、自分の意図通りでない結果を得たためにその人は、勢力がより大きいとはな らないはずである。このことからも、交渉の結果において示される統制の大きさからだけでは、夫婦の 勢力関係は説明されえないことが示唆される。

考慮範囲に入っているいくつかの選択肢のうち、ある選択肢が他の選択肢よりも「よい」と主観的に 判断されるものを選好（preference）とすると［佐伯，1980：8］、いくつかあるパタンのうち各配偶 者が望ましいとする夫婦間の意思決定のありかたは、「意思決定における自分たち夫婦の関係について の選好」ということになる。これが実際の意思決定での交渉における自分の統制の大きさに反映されて 
いないかぎり、個人は、たとえ交渉において統制がより大きくても、自分の意図通りにできていない点

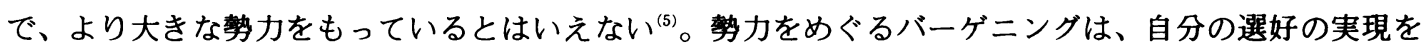
めぐるバーゲニングである。

したがって勢力関係は、意思決定場面における交涉の結果しか着目しないような統制アプローチでは 説明できない。つまり、その交渉より前の段階にある、意思決定における夫婦関係についての選好とい う概念を導入する必要がある。現代夫婦の勢力関係は、各配偶者の選好がどのようなものであるかとい う点から、どちらの配偶者の選好がより多く実現されるかという点まで観察するような、プロセスを重 視するアプローチによって説明される。統制は、意思決定場面での交涉においてではなく、むしろその ような選好の実現をめぐるバーゲニングにおいて捉えられるべきである ${ }^{(6)}$ 。そうすれば、統制の大きさ から勢力の大きさを導きだすことができる。

(2) パーゲニング・モテル

現代夫婦の勢力関係は、意思決定における夫婦関係についての自分の選好を、より多く実現させるこ とを目標に行なわれるバーゲニングのプロセスを追うことによって明らかになる。これを図式化すると、 図ー2のようになる。

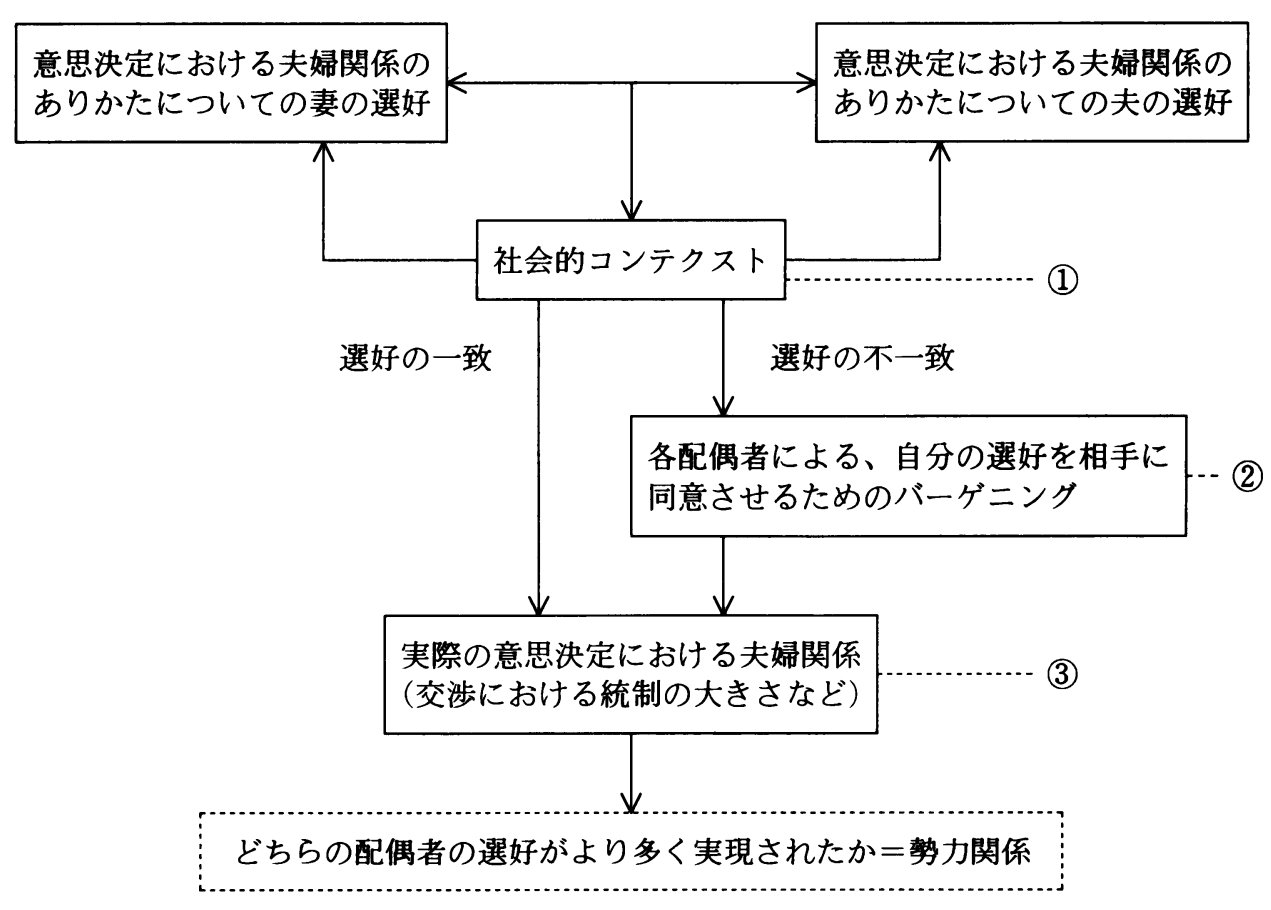

図ー2 バーゲニング・モデル 
意思決定における夫婦関係のありかたについての選好が夫婦で一致している場合は、二人の選好がと もに実際の夫婦間の意思決定に反映されるであろうから、まさに夫婦均等な勢力関係となる。それは、 たとえ実際の意思決定における夫婦関係が亭主関白的なものであってもである。なぜなら、両配偶者は そうした夫婦関係を選好しているからである。

一方、選好が不一致の夫婦は、四中(2)に示すように、各配偶者が相手を自分の選好に同意させようと するバーゲニング、つまり勢力をめぐるバーゲニングを開始する。

このバーゲニングにおいて社会経済的資源が交換されているか否かについては、今回の調査では検証 できなかったが、規範的資源説が否定されない限り、その可能性は考えられる。しかしここでは、交換 されるものを社会経済的資源に限定せず、まだ仮説的に述べられている概念ではあるが、スキャンゾー ニとポロンコの社会的コンテクストという概念に拡張したい（困中(1)）[Scanzoni and Polonko, 1980］。 彼らによると、社会的コンテクストには、社会経済的資源などの有形資源はもちろん、説得能力などの 無形資源や、相手との過去の交涉を振り返ることによってなされる方向づけ、属性（その人がどのよう な規範を内面化しているかを決定すると考えられる）、利害関心の程度なども含まれる。これらの社会 的コンテクストは、選好を実現させようとするバーゲニングのみならず、各配偶者の選好にも強い影響 を及ぼしているはずである。プロセスを重視して勢力関係を捉えようとすると、こうした概念は重要で ある。ただしスキャンゾーニらは、これらの社会的コンテクストを調査においてどのように捉えるべき かについては言及していない。

こうした社会的コンテクストにおける交換を通して、各配偶者はそれぞれの戦略を立て、自分の選好 を実際の意思決定に反映させようとバーゲニングを行なう。このプロセスを通して、四中(3)実際の意 思決定における夫婦関係が生ずる。したがって、この3が生じた後の時点で、夫婦の勢力関係を知るこ とが可能となる。なぜなら、この時点になって初めて、どちらの配偶者の選好が結局より多く実現され たのかが捉えられるからである。

もしどちらかの配偶者が現在の夫婦間の意思決定のありかた ${ }^{(7)} に$ 強い不満をもつようになったとすれ ば、同時にその人の夫婦関係についての選好は変化しているだろう。するとまた、夫婦は新たにバーゲ ニングを開始する。

現代日本の夫婦の勢力関係は、以上のようなプロセスを追うことによって、より多く明らかになる。 このようなプロセスを重視したアプローチは、既存のアプローチを発展させるものとして可能性を多く もっている。

\section{5. 今後の課題}

これまでわが国では、夫婦の勢力関係を調査によって明らかにしようとするさいには、つねに権威ア プローチが採用されてきた。しかし本論において、そうした方法はもはや有効でないということが実証 された。また、交渉の結果にしか着眼しない統制アプローチも勢力関係を説明できないことも分かった。 結果のみならずプロセスをも視野に入れることを重視し、本論では、選好という概念を用いて、新しい モデルの仮説的提示を試みた。

今後の課題としては、意思決定における夫婦関係のありかたについての各配偶者の選好をどのように 
して捉えるか、選好を規定するものは何か、そして実際の意思決定における夫婦関係において、各配偶 者の選好が実現されるための決定要因について追究することである。つまり、選好および社会的コンテ クストについての追究が必要である。いずれにせよ、本論で提示した、新しい勢力研究のための仮説的 モデルの有効性を実証することが課題である。

[付記] 本稿作成にあたっては、甲南大学大学院野々山久也教授のご指導をいただいた。また調査デー 夕に関しては、兵庫県家庭問題研究所の調査報告書を活用させていただいた。それぞれに深く 感謝申し上げたい。

\section{注}

（1）夫婦関係の対等化については、夫婦の役割関係についての既婚女性の考えかたの変化からもうかが える。厚生省が1993年に行なった「全国家庭動向調査」によれば、「夫も家事や育児を平等に分担す べき」と考える既婚女性は73.9\%もあった。1972年に総理府が行なった「婦人に関する意識調査」で、

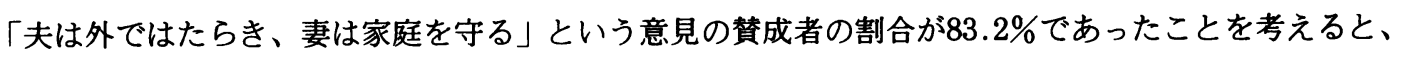
夫婦は対等であるべきとする考えかたは、この20～30年間でかなり浸透してきているといえる。

(2) 選挙人名簿には通常、世帯主に続いてその配偶者の名前が載っている。このことを利用して、夫が 健在である妻をサンプリングした。もし誤った標本を抽出した場合でも、フェイスシートでの回答か ら無効回答であることが分かり、分析から除外できる。また、この方法によると、夫婦別姓の妻はサ ンプルから除外される。

（3）調查ではこの他に、子どもの習い事や住居の場所などの項目も扱ったが、どの夫婦にも共通して意 思決定されることがらであり、且つ比較的最近に意思決定されたことがらであることを重視するため、 これらの6 項目だけについて分析する。

(4) 職業的威信は、管理職、専門・技術職、販売職、事務職、サービス職、現業職、農林漁業、パート、 学生、専業主婦・無職の順に低くなるとした。妻の職業でもっとも多いのは専業主婦であり（43.7\%）、 次いでパートが多い $(18.8 \%)$ 。夫の職業でもっとも多いのは管理職であり $(22.0 \%) 、$ 次いで事務 職（19.9\%）となっている。また、夫で無職が13.3\%であるのは、中高年層にサンプルが偏っている ことによる。

(5) ある人の選好を意困と同一視することについては、議論の余地があるが、ここでは明確な定義を行 なう前の段階として、そのような問題を留保する。

(6) この点について、クロムウェルとオルソンの、勢力は「基礎」「プロセス」「結果」の 3 領域を包 括的にみなければ捉えられないという主張と一致する [Cromwell and Olson, 1975]。ただ、クロ ムウェルらはこれらの 3 領域を意思決定場面だけに着目して扱っており、選好という概念が含まれな い。そこで筆者は、クロムウェルらの「基礎」には各配偶者の選好を、「プロセス」にはそれぞれの 選好を実現させるためのバーゲニングを、「結果」には実際の意思決定での夫婦関係を当てはめる。

（7）だれが意思決定において優位な立場にあるかということは、ある程度固定している。それは夫婦が、 勢力についての達成目標 [Kantor and Lehr, 1975]として、夫婦関係がどうあるべきかについて、 
パタン化された認識を共有しているためである。

\section{文 献}

Blood, Jr.R.O. and D.M.Wolfe, 1960, Husbands and Wives: The Dymamics of Married Living, Free Press.

Buric, O. and A.Zecevic, 1967, "Family Authority, Marital Satisfaction, and the Social Network in Yugoslavia", Journal of Marriage and the Family, 29, 325-336.

Burr, W.R., L.Ahern, and E.M.Knowles, 1973, “An Empirical Test of Rodman's Theory of

Resources in Cultural Contexts", Journal of Marriage and the Family, 39, 505-514.

Corrales, R.G., 1975, "Power and Satisfaction in Early Marriage", in R.E. Cromwell and

D.H.Olson(eds.), Power in Families, Sage Publications, 197-216.

伊藤富美, 1986, 『夫妻間の勢力関係の類型』, 風間書房.

Kantor, D.and W.Lehr, 1975, Inside The Family: Toward a Theory of Family Process, Jossey-Bass.（野々山久也訳，1990，『家族の内側一家族システム理論入門一』，垣内出版．）

菰㴊緑，1992，「勢力構造」，野村哲也編，『現代日本の夫婦関係一夫婦関係の变化に関する実証的研

究一』, 関西家族研究会, 39-57.

Kolb, T.M. and M.A.Straus, 1974, "Marital Power and Marital Happiness in Relation to Problem-Solving Ability", Journal of Marriage and the Family, 36, 756-766.

増田光吉, 1965, 「現代都市家族における夫婦及び姑の勢力構造一神戸市の場合一」，『甲南大学文学 会論集』, 社会科学編, 27, 49-66.

野々山久也，1996，「家族新時代への胎動一家族社会学のパラダイム転換に向けて一」，野々山久也・ 袖井孝子・篠崎正美編，『家族社会学研究シリーズ(1)いま家族に何が起こっているのか一家族社会 学のパラダイム転換をめぐって一』, ミネルウァ書房.

Olson, D.H. and C.Rabunsky, 1972, "Validity of Four Measures of Family Power", Journal of Marriage and the Family, 31, 545-550.

Rodman, H., 1967, "Marital Power in France, Greece, Yugoslavia and United States: A Cross-National Discussion", Journal of Marriage and the Family, 29, 320-324.

佐伯㭌, 1980, 『「きめ方」の論理一社会的決定理論への招待一』, 東京大学出版会.

Scanzoni, J., 1979, “Social Processes and Power in Families", in W.R.Burr, F.I.Nye and

I.L.Reiss(eds.), Contemporary Theories about the Family; Vol.1, Free Press.

Scanzoni, J. and K.Polonko, 1980, “A Conceptual Approach to Explicit Marital Negotiation

", Journal of Marriage and the Family, 42, 31-44.

Wolfe, D.M., 1959, "Power and Authority in the Family", in D.Cartwright(eds.), Studies in Social Power, Ann Arbor, Univ.of Michigan. (千輪浩監訳, 1962, 『社会的勢力』, 誠心書 房, 128-150. )

（財）兵庫県長寿社会研究機構・家庭問題研究所，1996，『夫婦の勢力関係に関する調査研究報告書』. （かたおか よしみ・甲南大学） 


\section{Marital Power in Present-day Japan: Application of the Bargaining Model}

Yoshimi Kataoka

Key words : marital power, preference, bargaining process

This paper develops a theoretical model to measure marital power in present Japanese society. The Authority Model, which many Japanese researchers use, may be valid in cases when one spouse is socially assigned more authority over the other. In current Japanese society, however, husbands and wives have come to be assigned authority evenly. It therefore seems more appropriate to discuss power in terms of control of negotiations. While 1995 research data from the Hyogo Prefectural Research Institute of Family Issues reveal the limitations of the authority approach, they do not specifically address the approach of discussing power by measuring control in negotiations.

These results suggest that it is no longer possible to explain marital power through the decision-making process alone. Rather, it would be more valid to note how much one spouse's preferences about his or her marital relationship in decision-making situations were realized over that of the other spouse in actual decision-making situations. With this approach, it would be necessary to follow-up on the bargaining process between spouses during decision-making, clarifying the preferences of each spouse, and seeing which spouse is able to realize preference.

\section{Japanese Wives' Perception of Fairness in the Division of Household Labor}

Akiko Iwama

Key words : equity perceptions; division of household labor; marital power structure

This paper investigates determinants of wives' perceptions of equity in the division of household labor in Japan. Running a regression analysis on data from 253 female respondents clarified the following five points. First, the greater the husband's actual contributions to housework were, the less likely the wife was to see housework as unfairly divided. Second, the demand of housework as represented by the number of children, and the wife's human capital to conduct household labor also determined the sense of justice in the division of labor. Third, more egalitarian-minded wife tended to see her existing arrangement as unfair. Fourth, woman with less power in relation to her husband was less likely to view a given division of housework as fair, while woman who held more power evaluated the same division as unfair. Finally, the higher the husband's socio-economic status was, the less likely the wife was to see housework as unfair. 